EDWINA PIO \& PAUL MOON

\title{
Third Worlds, Coolie and Coolitude: Unravelling the long arm of history
}

\section{Abstract}

Sugar dictated the fortunes of many countries in the British Empire in the nineteenth century. With the abolition of slavery, thousands of indentured labour or coolies from the Indian subcontinent, filled the labour gap. The word coolie was derogatory, referring to a marginalized underclass, whereas the word coolitude evokes and acknowledges agency. Our article revolves around the question: How does a historical lens evoke understandings of ethnic minorities (EM) at work in contemporary organisations? We illuminate a historical lens (the eternal present and linear progression, historical determinism and structuralism, and evoking the past), to provoke reflections on how on-going marginalisation of ethnic minorities at work, may be tethered to a coolie template. We weave conceptual understandings of history, indentured labour and EM in an interdisciplinary manner to evoke Recipient of The Royal Society Te Rangi Hiroa Medal and Duke of Edinburgh Fellowship, Fulbright alumna Edwina Pio is New Zealand's first Professor of Diversity, University Director of Diversity and elected Councillor on the governing body of the Auckland University of Technology. 
reflection by policy framers and managers on how the long arm of history may be implicated and unravelled. We suggest that such insights are necessary to highlight perceptions of coolitude as an alternative epistemology pertaining to EM at work.

\section{Keywords}

coolie, coolitude, ethnic minority, historical lens, work

\section{Introduction}

With global mobility and increasing diversity in organisations, there is an exigent to evoke historical lenses (Decker, Hassard \& Rowlinson, 2020), to explore more deeply the long arm of history, with reference to contemporary marginalisation of ethnic minorities (EM) at work. EM are indiivduals whose visible diversity discriminators provide markers of their ethnicity as for example skin colour that is not white. We provide an example from indentured labour on sugar plantations, for sugar and its consumption was closely bound with colour and white sugar served to purge the impure raw material which was produced by coolie labour (Knight, 2009). As Goffe (2019) writes: "within a single grain of sugar the human traffic of the centuries-long history of globalization is encrypted" (p. 34). The world's oceans were networked sites for the deployment of indentured labour. Sugar was important for world 
commerce and the sugar trade launched economic opportunities (Mintz, 1986; Ronback, 2014).

Against the backdrop of abolitionism in 1834, indenture was established leading to interconnectedness and seismic shifts of large swathes of individuals from the Indian ocean (Brandon, Frykman and Roge, 2019) across the Pacific and Atlantic. Between 1842 and 1917, more than a million individuals from the Indian subcontinent were sent to Fiji, Southern Africa, West Indies and Mauritius, through the statesponsored indenture system in the British Empire (Connolly, 2019). Our focus is on how a historical lens, influences, entangles with, reverberates and (re)makes contexts in contemporary times. As Hofmeyr (2007) suggests, "we need urgently to start writing the histories of this emerging present" (p.25). While this is a broad sweep of history, it is relevant today in an era where EM continue to be subjected to discrimination. Our article revolves around the question: How does a historic lens evoke understandings of $\mathrm{EM}$ at work in contemporary organisations? Our dual contribution is firstly, to foreground how conceptions of history have created a 'coolie template' which lingers in organisations in how EM are perceived.

Secondly, we show how evocation of the past results in ways that influence current organisational practices and perceptions wherein inferior and nonwhite are equated and coolitude is discounted. We 
do this through an exploration of indentured labour in Fiji sugar plantations and through contemporary experiences of EM at work across different countries. Hence, we weave conceptual understandings of history, indentured labour and $\mathrm{EM}$ in an interdisciplinary manner to evoke reflection by policy framers and managers on how the long arm of history may be implicated and unravelled. We suggest that such insights are necessary to highlight perceptions of coolitude as an alternative epistemology pertaining to EM at work, who are often seen as "coming to Third World the First World” (Roopnarine, 2009: p. 108).

The word coolie was derogatory referring to a marginalised underclass. While its etymology is unclear, it may be derived from the Tamil word 'kuli', Hindustani 'quli', or Turkish 'kul' meaning slave (Bahadur, 2013). The word coolie was banned in 1915 (Kaplan \& Kelly, 1999), but its impact lingers. Bates (2017) and Bragard (1998) argue that (mis)representation and (re)construction of indentured Indian labour in colonial archives, defocuses the agency and analysis of coolies, silencing their voices and trapping them in Westerncentric perspectives. Such thinking was generally based on epistemologies of the North premised on Eurocentric hegemonic thinking entrenched in "representing the world as one's own and of transforming it according to one's own needs and aspirations" (Santos, 2018: 6). Such epistemologies 
"conceive of the Eurocentric epistemological North as the only source of valid knowledge, no matter where, in geographic terms, that knowledge is produced...the South is the problem; the North is the solution" (Santos, 2018:6). Therefore, there is need for epistemologies of the South "to erase the power hierarchies inhabiting" the North (Santos, 2018:7), and to unravel knowledges of Western male colonizers (Grosfoguel, 2012).

The idea of 'coolitude' (Carter \& Torabully, 2002) is an intellectual interpretation of various incarnations of coolie as exile, with shared history and spaces for identity (de)construction. Coolitude includes the voyage as a site of trauma and loss, suffering and survival, but also a world of new encounters and revalorises "the term 'coolie' turning a term of abuse against itself in a form of empowerment" (p. 10). Coolitude has multiple meanings and can mean a new kind of consciousness with identity rooted in diversity, plurality and change (Bragard, 1998; Ette, 2017; Leetsch, 2019). Smith, et.al., (2004) encourage researchers to explore the interaction effects of race, gender, role and how historical and/or geographical issues may affect perceptions of diversity. This can lead to a radical reappraisal of how organisations are conceptualised, and how the past can inform current attitudes, contextualise perceptions of the present and (mis)prescribe aims for the future. 
The concept of coolitude turns negative connotations of coolie into positive perceptions of EM emblematic of diversity, evoking a praxis of equality. While it can be argued that much is already known about discrimination and EM, the merit of this article is investigating how history has posthumously ossified perceptions. These perceptions become a default modus operandi in how EM are analysed and managed. We have not explicitly engaged with theoretical frames of postcolonialism, anti-colonialism and decolonial inquiry, as we believe that a broad historic lens provides a much larger arc for eliciting understandings of EM. We argue that policy framers may have moved away from the past in a strictly chronological sense, but beliefs, perspectives and prejudices are not necessarily distanced by time. Our historical lenses include the eternal present and linear progression; historical determinism and structuralism; and evoking the past.

The next section focuses on select conceptions of the long arm of history. This is followed by a brief expose of the sugar coolie experience in Fiji. Next, we explicate coolies and coolitude as experienced by EM at work in contemporary organisations. Finally, we suggest questions which organisations may choose to engage with and discuss the implications of our study, followed by concluding comments. 


\section{The long arm of history}

In seeking to delve into the long arm of history, the 'uses of the past' perspective, have the capacity to shift what Kosseleck (2004) calls the 'horizon of expectations'. Decker, Hassard and Rowlinson (2020) emphasise a reorientation requirement in how management is studied to widen and deepen engagement with history beyond the binary debate of memory and history. They call this historiographical reflexivity where both history and collective memory are engaged with through a repertoire of methods. History can be used both as a source of data and method, keeping in mind past contexts and this "engenders greater plurality in how the past can be researched" (p. 5). Historiographical reflexivity provides opportunities for "engaging with marginalized and rarely studied groups...in terms of gender and professions...capturing diverse voices in organizations...with a more interpretive and constructionist view of the past..." (pp. 23-24).

This affects the way in which firms mediate between the technical realms of the factors of production, and symbolic resources such as legitimacy, status and reputation (Suddaby, Foster, \& Trank, 2010), and how organisations themselves can be melded into perceptions of a country's national identity and memory as part of a national cultural-historical framework (Mordhorst, 2014). The past can also be appropriated to provide 'plotted stages' of an 
organisation's narrative (Popp and Holt, 2013) - one which runs in parallel with broader national narratives about progress over a given period. It allows for the past not just to be observed and understood, but to be framed in ways that justify and explain current practices and that it benefits the business in certain ways (Booth \& Rowlinson, 2006). The past can be drawn on for validation of current practices (Kosseleck, 2004) and can lead to 'the creation of certain narratives' about the purpose, function, and character of the organisation (Hansen, 2006). Hence, the uses of the past can occur without deliberate intent, but more through the organisation's culture and values being subconsciously assimilated (Zick, Wagner, Van Dick, \& Petzel, 2001).

The idea of an immanent (Cowen \& Shenton, 1995) retention of earlier ideas wherein an organisation might unwittingly accrue approaches/beliefs of predecessors is akin in some ways to a form of apostolic succession that traces practices and values back to or near to the origins of the organisation. By contrast, Wallerstein has argued that lingering prejudices are not incidental and inadvertently acquired but are an essential coordinating principle of organisations (Balibar \& Wallerstein, 1991; Wallerstein, 1990). Table I presents uses of the past and theoretical elements 
Table I: Uses of the Past and theoretical elements

Eternal Present - All that matters, and all that is worth analysing is what is occurring now, or in the present type of environment.

- The present represents the best of all possible worlds.

- Relies on a near-static form of reality.

- Organisational structures and processes are devised and revised with little reference to the organisation's history.

Linear Progression of

- Implicit or explicit in organisational studies, presumes

History that racism and sexism will no longer be influences the present.

- In organisations, racism and sexism are not part of policy, but are manifested in practice.
Historical Determinism - Implies that to some extent, the present is pre- determined by the past.
- Organisations inherit practices and processes with little awareness of this process occurring.

Historical Structuralism - Accounts for how patterns of behaviour and exploitation are in-built into societies and organisations.

Evoking the Past - The past is evoked and applied not primarily as a means of understanding what has gone on before, but more as an ideological tool

- Because of the selectivity of this approach, in the context of management, such evocations can be drawn on as justifications for arrangement of policies, structures, and processes.

Eternal present and linear progression

The concept of the 'eternal present' (Gherardi \& Strati, 1988; Fournier, 2006) is one in which all that matters is what is occurring now, as history follows a linear progression to arrive at a destination which is the best of all possible worlds (Enfu \& Xiaoqin 
2012; Hankinson, 1989). The past is discounted as irretrievable or dismissed as based on memories irrelevant to the present (Booth \& Rowlinson 2006), while the future is unknowable and only has significance as a place to locate expectations (Clark \& Rowlinson, 2004). Many developments in businesses, occur in jurisdictions that forbid, through legislation, discrimination on the basis of race, gender, religion, and related criteria, that nonetheless enables the survival of earlier prejudices in the organisation's 'DNA' and even circumvent detection, let alone censure (Amos \& Parmar, 1984; Griffith, et al, 2007; Lopez, 2000). This suggests a form of eternal recurrence at play (Merry, 2009; More, 2010). Hence, while management may have moved away from the past in a strictly chronological sense, beliefs, perspectives and prejudices are not similarly necessarily distanced by time. Allied to this is the concern that if the present is believed to be the best of all possible worlds, then any elements of the past that have survived to the present constitute part of 'the best'. This can include discriminatory ways of seeing certain groups in an organisation.

Hence, gender, ethnic, religious, and other categories of discrimination which might be historically based, need to be maintained for some organisations, and even states, to function in the manner that they do (Hopkins and Wallerstein, 1977). This analysis exemplifies the conscious, 
deliberate, and persistent use of history to maintain gender, ethnic, religious and other inequalities within management. Moreover, these inbuilt inequalities have the capacity to orient the behaviour of groups within the organisation in ways that perpetuates them (Ackroyd, \& Fleetwood, 2000; Agocs, \& Jain 2001; Wallerstein, 1987).

One argument for the significance of the eternal present - almost as a static form of reality - was advanced by Francis Fukuyama (1992), whose notion of the 'end of history' implied among much else that ideological evolution had reached a type of stationary state. According to Fukuyama, events in the twentieth century had proven the total exhaustion of viable systematic alternatives to Western liberalism' (Fukuyama, 1989), and so all that remained was for society and its constituent elements to continue to reproduce the perfection of the present (Fournier, 2006; Hodgson, 1999). However, such views are based on the belief that history follows a linear progression to arrive at a destination which is the best of all possible worlds (Enfu \& Xiaoqin 2012; Harkinson, 1989). We argue that the implicit presumptions that govern organisational attitudes and behaviours towards $\mathrm{EM}$ at the present time are in large part dictated by an historical inheritance extending back at least to the nineteenth century, when notions about the roles and status of indentured individuals were formed. Implicit in this linear approach to history is 
the belief that the present represents a refinement and improvement of the past, in which more liberal and enlightened values have achieved an ascendency (Brigman, 2012; Olson, 1993).

Historical determinism and structuralism

There is a clear seam of historical determinism running through the notion of 'uses of the past', which rests partly on the concept that what happens now is predetermined and/or constrained by various historical trends. Hegel espoused a strong form of determinism, in which he acknowledged the capacity for free will, but argued that this free will was exercised in a universe governed by pre-existing necessary laws (Parkinson, 1972). In the context of this article, an element of Marxist determinism (which distils some of Hegel's determinism) has a strong bearing: namely, that the economic aspect of social reality determines non-economic aspects such as in the political, social, and cultural realms (Resnick \& Wolff, 1982). An apparent parallel exists between this principle and organisations, in which their histories determine not only the financial/economic aspects of their culture, but also the way in which the organisation categorizes and relates to different 'categories' of people. For example, indentured women, being 'natives' from the Indian subcontinent during the period of the British Empire, further legitimized the treatment by businesses of such natives being dirty, slovenly, 
wanton women, needing to be herded and pushed in order to do a good day's work (Gillion, 1962; Lal, 1985; Tinker, 1974).

In the case of sugar coolies in the nineteenth and early twentieth century, the links to perceptions of them seem to have held in contemporary times in how EM are managed in organisations. Where the residue of the perceptions have survived to the present day, a structuralist approach is useful, to account for how patterns of exploitation of this group in organisations maybe part of a broader system of exploitation (Callinicos, 1985; Frank \& Gills, 1996) based on former parts of the British Empire where indentured labour was prevalent. The structuralist dimension requires that the group under consideration, and the organisations for which they work, are considered as a subset of broader structures, such as the nation-state, ethnic/religious groups, languages, social class, and so forth (Pace, 1978). To some extent, this undermines the exclusivity of any claims that organisations are limited in the use of history exclusively to their own histories. For it is neither possible nor logical to attempt to segregate the history of an organisation from the environments in which it operates.

Evoking the past

How a business perceives itself and the people it has contact with is inextricably linked to how it 
understands not only its internal functions, but its relationships with the society in which it exists (Lawrence, 1984; Schultz \& Hernes, 2013). Part of the process of interpretation of the past depends on what historical material is available and then selected, and through which lenses it is thereafter viewed. The past is never fully recoverable (Eggins et al, 1993) and the act of reclaiming fragments of that past and assembling them in any given priority is necessarily a subjective undertaking (Weick, 1993). In making visible, invisible histories, epistemologies from the South represent the world in their own ways, with their own agency and power to dissolve the inferior perceptions of the South and its peoples and to encourage an ecology of knowledges (Santos, 2018). Here the South is not the opposite of the North, and while it may geographically exist in some parts of the South, such knowledges may also be produced in the North as there is an overlap between epistemologies and geographic spaces. As Santos (2018) powerfully writes "The epistemologies of the South occupy the concept of epistemology in order to re-signify it as an instrument for interrupting the dominant politics of knowledge" (p. 2). Syed et al., (2018) stress the need to build and maintain coalitions to reform the current status quo, as "inequities are a consequence of the power conferred to the dominant group-both historically and contemporarily-that have shaped 
the different lived experiences between 'majorities' and 'minorities"' (p. 822).

Evoking the past employs history as an ideological tool (Rostow, 1990; Schultz \& Hernes, 2013) in which specific stages of historic development are sculpted, and experiences of ethnic, social, and other groups contextualised and confined by each stage (Engerman, 2003; Tatenhove, Arts, \& Leroy, 2000). This lens may have a direct bearing on the institutional, cultural, religious, gendered and social strands of the past that affect contemporary organisational perceptions of specific groups in organisations. This can reinforce the notion that the racialized other was the quintessential Other (Brah, 1993) with direct and indirect discrimination in employment access, promotion, training, glass ceiling thresholds and racist caricatures globally such as in the UK, USA, Canada, Australia and New Zealand (Bhatia, 2007; Brah, 1993; Brown, 1984; Pio and Essers, 2013; Pio \& Syed, 2020). In the case of the late nineteenth and early twentieth century status of coolies, the use of history has been an element in maintaining and perpetrating prejudices in contemporary organisational practices across the globe.

The next section focuses on scenarios of coolies in Fiji as one possible interpretation, of how the long arm of history continues its vice like grip. It is not our intention to provide scenarios from all geographic locations where sugar work took place. 
The Fiji example is intended to serve as a catalyst for organisations to explore a broad swathe of questions linked to how various processes may be interlocked in a historical stasis that paints EM as servile workers with minimum agency.

\section{Sugar coolies and the past}

Schneider, Jr. (1926) in his work on sugar and its importance to world commerce, writes of the honey bearing reed from India, known to Alexander the Great, traded on the great medieval routes with Venice as the hub. This hub later moved to London where sugar consumption in Great Britain increased from 10,000 tons in 1700 to 150,000 tons in 1800. Ronback (2014) emphasises the transnational interdependence of the early modern sugar trade in the $18^{\text {th }}$ century with a focus on the Caribbean and argues that this trade opened many economic opportunities for various agents including that of the slave trade. With the abolition of slavery, Indian indentured labour moved into lines previously inhabited by African slaves if not in reality, then in imagination as in the case of Fiji and the colonies (Tinker, 1974).

With the expansion of railways, Indians in the nineteenth century travelled to the port cities of Calcutta and Madras from the interior of India which was over crowded, ravaged by floods, droughts, famine, communal conflict, decay of commercial facilities based on the industrialised 
competition of cotton and cloth and the 1857 sepoy uprising in India. Indenture was organised through emigration agents in Calcutta and Madras, where the Agent general of Immigration, later known as the Protector of the Immigrants (Reddock, 1986) along with their staff were responsible for the health, food, working conditions and if necessary prosecution of estate owners who did not adequately provide for health, food and working conditions. The agents recruited from markets, railway stations, bazaars, temples and fairs (Reddock, 1986).

Indentured Indians were called girmityas, from the English word agreement. 60,537 indentured individuals from India travelled to Fiji, aged 20 to 30 years, where they were contracted to work for a minimum period of five years at 1 shilling per 9 hour working day and for women it was 9 pence (Narsey, 1979). But on arrival in Fiji this changed to task work and if the task was not complete, the workers were fined and made to labour without pay till the task was completed, which allowed leeway for extraction, irrespective of the world price of sugar. Coolies were unprotected, had no rights to own land, though they supplied the labour on the sugar plantations necessary for the company, the Colonial Sugar Refinery, to make large profits (Alam et al., 2004). The "Indian labourers received about $2 \%$ of Fiji sugar export proceeds, white planters received 36\% after labour expenses..." (Knapman, 1985: 69) 
and most sugar export income went to the company during the period 1882-1939.

Indentured labourers became objectified, and race came before class as an organizing principle for British industrial production (Kelly, 1992). For the five years the girmitiyas belonged to the European planters and the overseers reduced all Indians to one level as they were generally ignorant about Indian culture, disliked Indians who were believed to be sinister and hard to control but fit for tropical manual labour (Kelly, 1988, 1992). Indian coolies were considered the "scum of India", "the lowest class", only fit to be labourers, animalistic by nature and as a race inferior to Europeans. There was sexual abuse of the coolie women, polyandry and lack of recognition of Indian marriages due to demographic imbalances in the coolie lines, 'irregular marriages' and 'conniving Indians' (Kelly, 1989, 1990, 1991).

Indians were labour units for the colonial enterprise, a horde of heathens from the point of view of missionaries and a source of contamination by the medical officers and health officials (Kelly, 1988; Gillion, 1977). Hence, sugar labour dismantled the dignity of coolies casting them as chattels in the service of Empire. The next section touches on coolitude in the present. 


\section{Coolitude in the Present}

We acknowledge that there exists an immense body of rich scholarship on the various nuanced, explicit and implicit discrimination towards EM, that continue in contemporary organisations. While the scope of this article, does not include a comprehensive overview of discrimination towards EM, it does provide extant examples of coolitude. We reiterate that while there exist a host of interpretations in the analysis of these EM situations, they have generally not gone deep into historical linkages as to why these situations persist across the world. We touch on agentic examples, to problematize the colonial face of knowledge and practice which subalternises alternatives and knowledges. This can be linked to the minority tax, racial fatigue and a struggling diversity climate.

Despite increasing evidence as to the disparities EM face in many occupational sectors including hidden inequalities, inequality regimes, and matrices of visibility regimes (Munkerjord, 2019; Nkomo \& Rodriguez, 2018; Wasserman \& Frenkel, 2019), actions have been 'unacceptably slow' with representation at senior roles and in careers for global health research and academia in the UK, in spite of diversity policies (Khan et al., 2019). A British example, (Ogbonna, 2019), highlights the uneasy alliance of EM and organisational culture resulting in continuing disparity of outcomes in the labour market, which have hardly improved despite 
government advice and diversity policies. Undoubtedly there is need to consider the intersectionality of gender and ethnicity in understanding the workplace experiences of EM to move away from static identities and single identity categories in how systems of domination are enacted (Brah, 1993; Opara, Sealy \& Ryan, 2020).

Indians in the US are often exposed to a xenophobic environment with discriminatory practices based on their race and multiple ecological systems (Inman et al., 2015). These authors attribute some of this to British colonial rule and vestiges of British imperialism with a strong dependence on British identified values such as light skin colour, use of English language and social class. Chakravartty (2006) emphasizes exploitation of high-tech Indian migrants in the US and refers to them as indentured servants in high tech electronic sweatshops or techno slaves who will accept exploitation, racial discrimination and servility, in their desire for the coveted green card.

Yet, considering EM's agency and leadership in cultural, social and political domains (Gottardo \& Cyment, 2019; Hennekam \& Bacouel-Jentjens, 2019; Ogbonna, 2019; Zanoni \& Janssens, 2007), can help promote coolitude. It is pertinent to note that some 'coolie' generations are among the most prosperous segments of society in South Africa, Guyana and Trinidad (Bates, 2017). Further, the various regulations which governed colonial coolies, 
were used by the League of Nations to set up the International Labour Organisation (Bates, 2017). These examples can be viewed as part of the notion of coolitude despite the invisible tenacity of history through the case of sugar coolies. Agentic strategies are a combination of resistance and compliance, to oscillate between different subject positions and shifting strategies to balance advantages and disadvantages, based on various manifestations of power (Van Laer \& Janssens, 2017). This signals the need for structural change and this is where organizations can play a significant role to circumvent discourses of inferiority through institutionalizing appropriate policies and practices which fracture colonial prisms and negate the long arm of coolie history, to endorse coolitude.

In a Belgian study, Van Laer and Janssens (2017) challenge the notion of EM as passive individuals and victims of structures and focus on agency in the face of dominant discourses through resistance, struggle, contradictions and tensions with power and control in "an ambiguous and complex interplay of mutual constitution" (p. 199). In the case of Spain and the UK, Cederberg and Villares-Varela (2019) note how EM entrepreneurs navigate various opportunities despite structural constraints, thus displaying agency through strategic mobilisation of their own cultural capital including their ethnic image. This is like how EM women transcend othering through their own agency and 
transnational networks (Pio \& Essers, 2013). EM women from Poland, Latvia and Hungary, are portrayed as displaying resilience, rejecting binary categories of agency and victimhood, and highlighting a diversity of responses, rather than one-dimensional constructions of agency (Rydzik \& Anitha, 2019). Another example is that of SouthAsian Muslim women in the UK using their own agency and various strategies to overcome complex obstacles in employment and career progression, as active agents in choices and outcomes (Tariq \& Syed, 2017). Tomlinson et al. (2013) discuss the legal profession in England and Wales and emphasise that agency has past, current and future elements which tend to reproduce rather than transform various structures. They note the 'rarity of structural reform... and where firms appear to endorse equal opportunities, old opportunity structures and inequalities endure" (p. 247). In Australian and UK workplaces, EM Muslim women use active emotion-focused coping along with planning to handle discrimination (Murray \& Ali, 2017).

Syed et al. (2018) discuss the invisibility of knowledge produced by EM and how dominant practices overlook such knowledge by silence and dismissal. They discuss ideological settings which are undergirded by broader values and beliefs for research practice based on mainstream perspectives in the field which are overwhelmingly white and 
Western. This ties in with invisibility of representation for various appointments which often goes unchallenged and unmonitored based on systemic levels of invisibility.

Table II presents some questions to unravel the long arm of history as an avenue for a deep exploration of the current status of EM in organisations.

Table II: Questions to explore and reflect on to unravel the long arm of history

- When and why was the organisation founded?

- How have these origins changed or remained static?

- How have the origins impacted diversity in the organisation with reference to recruitment, selection, career progression?

- What is the profile of board members and policy creators? Why?

- What aspects of training and development need to be changed in view of the current demography?

- What are the optics the organisation wants to portray to its stakeholders? Why?

- What needs to be cherished and what needs to be chucked in these optics?

- How can corlitude be brought into the organisation?

- What is the frequency of monitoring the experiences of EM? How is this enacted to ensure transparency and public reporting?

- How can epistemologies of the South or different knowledges be located in organisational policies and practices?

It is suggested that a regular review of these questions along with an audit for actionable responses, would be useful for ensuring that 'coolitude' becomes embedded in organisational 
processes and practices. This is a potent reminder that we are circumscribed by our history (Decker, Hassard, \& Rowlinson, 2020), and hence a deeper understanding of its long arm will serve as a pathway to evoking more positive experiences for $\mathrm{EM}$ in organisations. It is here that the currency of epistemologies of the South can affirm new constructions of EM with greater cosmopolitanism and promote pluriversality (Santos, 2018), while eschewing connotations of coolie and emphasizing coolitude.

\section{Discussion and Concluding comments}

Through this article, we have put forward a historical perspective which brings to the fore resistance-conformity dynamics involving colonizers and colonized at large to challenge the Eurocentric feature of 'history' itself from the perspectives of multiple and heterogeneous racialized others. Thus, there is focus on agency along with discrimination experienced by EM to expel notions of coolie and provide alternatives to Western-centric perspectives (Bates, 2017; Bragard, 1998; Mongia, 2004). This article embraces the past in order to shed some glimmers of light to contemporary issues pertaining to EM in management studies. More particularly, this research adds to postcolonial and decolonial accounts on management and growing debates on the eventual radicalization of elitism and racism connected to white supremacists within 
management studies as a response to the emergence of critical accounts from peripheries of global capitalism.

This article illustrates one way in which management can choose history to explore and reflect on practices in organisations (Decker, Hassard, \& Rowlinson, 2020), with specific reference to EM. Therefore, there is movement away from Eurocentric fundamentalism which can be construed as a machine of 'epistemicide' (Santos, 2018) which privileges "the knowledges, memories and histories of the Westernized male colonizers throughout the world" (Grosfoguel, 2012: 83). Accordingly, our article engages with EM and the past, to foreground knowledge and practices which have been subalternized, marginalized and inferiorized by Eurocentric modernity in general and the Westernized university in particular.

One of the principal themes that is evident from this study is that the notion of the eternal present as the 'default position' from which organisations are interpreted, understood, and represented, can risk ignoring the significance of history in management studies. Economic exploitation and its many faces including unemployment, underpayment, and underemployment continue for EM. What is apparent is that this influence can take on immanent or intentional forms, and rather than being an incidental aspect of an organisation or economy, can extend to be core principles, including 
the persistent role of sexism and racism. The notion of historical determinism explains the reasons why the uses of the past carry such influence on present practices and beliefs, while structuralist arguments help to account for ways in which this inheritance transcends individuals and becomes embedded as part of the nature of organisations, societies, and economies. In such settings, the past is evoked not so much as a recollection of periods that are remote from the present, and seen as somehow less enlightened, but as an ideological tool to reinforce and legitimise previous values and prejudices in current environments.

Our article offers support to epistemologies of the South to (re)interpret, (re)construct and scrutinize the dominant knowledges of the North and formulate alternatives. As Santos (2018) compellingly argues with reference to the positioning of the South "such a task is as important today as it was at the time of historical colonialism, since the disappearance of the latter did not imply the end of colonialism as a form of sociability based on the ethnocultural and even ontological inferiority of the other..." (p.8). Yet we are quick to add that our article does not imply that all EM experience discrimination and that all EM display agency, just as all whites do not express colonial and discriminatory behaviours.

Our contribution is firstly to open up spaces for new conversations to include a historical lens in 
management scholarship; secondly to extend the definition of coolitude through agency and epistemologies of the South, in the conceptualisation of EM. In this process we spotlight EM where the native template and imperial imprimatur still has currency. The importance of assessing the role of history and of historical approaches when analysing the ways in which organisations function allows for a radical reappraisal of how contexts and EM are conceptualised. Additionally, such uses of the past can inform current attitudes, contextualise perceptions of the present, and prescribe aims for the future, with potential impact beyond academia. However, we acknowledge that researching other Empires (Spanish, Ottoman) may add a more nuanced view to coolies and coolitude. A historical view of recruiting agents who served as intermediaries for how recruitment was enacted, and which individuals were recruited/favoured is another fruitful research domain. Future research may investigate the disruptive strategies and enablers businesses identify, to integrate and view EM as sources of competitive imagination (Hart \& Sharma, 2004), rather than from a coolie view. Additionally, research can explore the creation of non-condescending workshops, which facilitate the valuing diversity philosophy for all groups, to enhance coolitude. Coolitude "gives us a new take on the literatures of the world and the world beyond 
literature, creating new concepts of understanding. It allows us to keep creating our world in poly-logical ways for and in new futures" (Ette, 2017, p. 118). And the powerful concept of epistemologies of the South are a step further in the direction of fragmenting the enduring legacy and lingering impact of indenture and the tarnished legacy in how EM are viewed in contemporary organisations. 


\section{References}

Ackroyd, S., \& Fleetwood, S. (2000). Realist perspectives on management and organisations. Psychology Press.

Alam, M., Lawrence, S., and Nandan, R. (2004). Accounting for economic development in the context of post-colonialism: The Fijian experience. Critical Perspectives on Accounting 15, 135-157.

Agocs, C., \& Jain, H. C. (2001). Systemic racism in employment in Canada: Diagnosing systemic racism in organizational culture. Toronto: Canadian Race Relations Foundation.

Amos, V., \& Parmar, P. (1984). Challenging imperial feminism. Feminist review, (17), 3-19.

Bahadur, G. (2013). Coolie woman: The odyssey of Indenture. Chicago: The University of Chicago Press Balibar, E., \& Wallerstein, I. M. (1991). Race, nation, class: Ambiguous identities. London, Verso.

Bates, C. (2017). Some Thoughts on the Representation and Misrepresentation of the Colonial South-Asian Labour Diaspora. South-Asian Studies, 33(1), 7-22.

Bhatia, S., 2007. American karma: race, culture and identity in the Indian diaspora. New York: New York University Press.

Boogaard, B., and Roggeband, C. (2010). Paradoxes of Intersectionality: Theorizing Inequality in the Dutch Police Force through Structure and Agency. Organization, 17(1), 53-75. 
Booth, C., \& Rowlinson, M. (2006). Management and organizational history: prospects. Management \& Organizational History, 1(1), 5-30.

Bragard, V. (2008). Transoceanic dialogues: Coolitude in Caribbean and Indian Ocean Literatures. Brussels, Belgium: P.I.E. Peter Lang

Brah, A. (1993) 'Race' and 'culture' in the gendering of labour markets: South-Asian young Muslim women and the labour market, Journal of Ethnic and Migration Studies, 19 (3), 441-458.

Brennan, L., McDonald, J., \& Shlomowitz, R. (1998) The geographic and social origins of Indian indentured labourers in Mauritius, Natal, Fiji, Guyana and Jamaica. South-Asia: Journal of SouthAsian Studies, 21 (1), 39-71.

Brandon, P., Frykman, N., and Roge, P. (2019). Free and unfree labour in Atlantic and Indian ocean port cities (Seventeenth-Nineteenth Centuries). International Review of Social History, 64(S27), 1-18. Brigman, D S. (2012). English History through the Historian's Eyes: Revisiting David Hume and Thomas Babington Macaulay. Doctoral Diss. University of Central Missouri, 2012.

Brown, C. (1984) Black and White Britain, London: Policy Studies Institute.

Callinicos, A. (1985). Postmodernism, PostStructuralism, Post-Marxism? Theory, Culture \& Society, 2(3), 85-101. 
Carter, M. and Torabully, K. (2002). Coolitude: An Anthology of the Indian Labour Diaspora. London: Anthem Press.

Cederberg, M., and Villares-Varela, M. (2019). Ethnic entrepreneurship and the question of agency: The role of different forms of capital, and the relevance of social class. Journal of Ethnic \& Migration Studies, 45(1), 115-132.

Chakravartty, P. (2006). Symbolic Analysts or Indentured Servants? Indian High-Tech Migrants in America's Information Economy. Knowledge, Technology, \& Policy, 19, (3), 27-43.

Clark, P., \& Rowlinson, M. (2004). The treatment of history in organisation studies: towards an historic turn'? Business History, 46(3), 331-352.

Connolly, J. (2019). Indenture as compensation: state financing for indentured labor migration in the era of emancipation. Slavery and Abolition, 40(3), 448471.

Cowen, M., \& Shenton, R. (1995). The invention of development. Power of development, 27-43.

Decker, S., Hassard, J., \& Rowlinson, M. (2020). Rethinking history and memory in organization studies: The case for historiographical reflexivity. Human Relations, $0(0), \quad 1-33$. https://doi.org/10.1177/0018726720927443

Eggins, S., Peter W., \& James M. (1993). The discourse of history: Distancing the recoverable past. Register analysis: Theory and practice 75-109. 
Enfu, C., \& Xiaoqin, D. (2012). Alternative thoughts and practice to contemporary capitalism: A response to Francis Fukuyama's criticism. International Critical Thought, 2(2), 127-138.

Engerman, D. C. (2003). Staging growth: Modernization, development, and the global cold war. Boston, USA: University of Massachusetts Press. Ette, O. (2017) Khal Torabully. "Coolies" and corals, or living in transarchipelagic worlds, Journal of the African Literature Association, 11(1), 112-1.

Fournier, V. (2006). Breaking from the Weight of the Eternal Present Teaching Organizational Difference. Management Learning, 37(3), 295-311.

Frank, G., \& Gills, K. (1996). The World System: Five hundred years or five thousand? London: Routledge. Freund B (1995). Insiders and Outsiders: The Indian Working Class of Durban 1910-1990. Pietermaritzburg: University of Natal Press

Fukuyama, F. (1992) The End of History and the Last Man. New York: Free Press.

Gherardi, S., \& Strati, A. (1988). The temporal dimension in organizational studies. Organization Studies, 9(2), 149-164.

Gillion, K. L. (1962) Fiji's Indian Migrants: A History to the End of Indenture in 1920. Melbourne: Oxford University Press.

Gillion, K. L. (1977) The Fiji Indians: Challenge to European Dominance, 1920-1946. Canberra: Australian National University Press. 
Goffe, T. (2019). Sugarwork: The Gastropoetics of AfroAsia After the Plantation. Asian diasporic visual cultures and the Americas. 5, 31-56.

Gottardo, C., \& Cyment, P. (2019). The Global Compact for Migration: what could it

mean for women and gender relations? Gender \& Development, 27 (1), 67-83.

Griffith, D. M., Mason, M., Yonas, M., Eng, E., Jeffries, V., Plihcik, S., \& Parks, B. (2007). Dismantling institutional racism: theory and action. American journal of community psychology, 39(3-4), 381-392.

Grosfoguel, R. (2012). The dilemmas of ethnic studies in the United States: Between liberal multiculturalism, identity politics, disciplinary colonization, and decolonial epistemologies. Human Architecture, 10(1), 81-89.

Hankinson, R. J. (1989). Galen and the best of all possible worlds. The Classical Quarterly (New Series), 39(01), 206-227.

Hansen, P. H. (2006). Networks, narratives, and new markets: The rise and decline of Danish modern furniture design, 1930-1970. Business History Review, 80(03), 449-483.

Hennekam, S., Bacouel-Jentjens, S., \& Yang, I. (2019). Ethnic diversity management in France: a multilevel perspective. International journal of Manpower, 40 (1), 120-134.

Hodgson, G. M. (1999). Economics and Utopia: why the learning economy is not the end of history (Vol. 11). Psychology Press. 
Hofmeyr, I. (2007) The Black Atlantic Meets the Indian Ocean: Forging New Paradigms of Transnationalism for the Global South - Literary and Cultural Perspectives, Social Dynamics, 33:2, 3-32.

Hopkins, Terence K., and Wallerstein. (1977) Patterns of development of the modern world-system. Review (Fernand Braudel Center) 111-145.

Inman, A., Tummala-Narra, P., Kaduvettoor-Davidson, A., Alvarez, A., \& Yeh, C. (2015). Perceptions of Race- Based Discrimination Among FirstGeneration Asian Indians in the United States. The Counseling Psychologist, 1-31.

Kaplan, M., \& Kelly, J. (1999). On Discourse and Power: "Cults" and "Orientals" in Fiji. American Ethnologist, 26 (4), 843-863.

Kelly, J. (1988). Fiji Indians and Political Discourse in Fiji: from the Pacific Romance to the Coups. Journal of Historical Sociology, 1 (4), 399-422.

Kelly, J. (1989). Fear of Culture: British Regulation of Indian Marriage in Post-Indenture Fiji. Ethnohistory, 36, (4), 372-391

Kelly, J. (1992). Fiji Indians and "Commoditization of Labor" American Ethnologist, 19 (1), 97-120.

Kelly, J, (1991). A Politics of Virtue: Hinduism, sexuality and countercolonial discourse in Fiji, University of Chicago Press, Chicago.

Kelly, J, (1990). 'Discourse about sexuality and the end of indenture in Fiji: the making of counterhegemonic discourse', History and Anthropology, 5:19-61. 
Khan, M. S., Lakha, F., Tan, M. M. J., Singh, S. R., Quek, R. Y. C., Han, E., Tan, S. M., Haldane, V., Gea-Sánchez, M., and Legido-Quigley, H. (2019). More talk than action: Gender and ethnic diversity in leading public health universities. The Lancet, 393(10171), 594-600.

Knapman, B. (1985) Capitalism's economic impact in colonial Fiji. 1874-1939: Development or underdevelopment? The Journal of Pacific History, 20 (2), 66-83.

Knight, G.R. (2009) A House of Honey: White Sugar, Brown Sugar, and the Taste for Modernity in Colonial and Postcolonial Indonesia, Food and Foodways, 17:4, 197-214.

Koselleck, R. (2004). Futures past: on the semantics of historical time. Columbia University Press.

Lal, B.V. (1985) Kunti's Cry: Indentured Women on Fiji Plantations, The Indian Economic and Social History Review 22: 55-71.

Lawrence, B. S. (1984). Historical perspective: Using the past to study the present. Academy of Management Review, 9 (2) 307-312.

Leetsch, J. (2019). Of Suitcases and Gunny Sacks: The Poetics of Travel in M. G. Vassanji and Shailja Patel. Kairos: A Journal of Critical Symposium, 4(1), 60-77 Lopez, I. F. H. (2000). Institutional racism: Judicial conduct and a new theory of racial discrimination. Yale Law Journal, 1717-1884. 
Merry, S. E. (2009). Human rights and gender violence: Translating international law into local justice. Chicago: University of Chicago Press.

Mintz, S. (1986). Sweetness \& Power. London: Penguin.

Mongia, R. (2004). Impartial regimes of truth: Indentured Indian labour and the status of the inquiry. Cultural Studies 18, (5), 749-768.

Mordhorst, M. (2014). Arla and Danish national identity-business history as cultural history. Business History, 56(1), 116-133.

More, M. (2010). The overhuman in the transhuman. Journal of Evolution and Technology, 21(1), 1-4.

Munkejord, M. C. (2020). Challenging the ethnic pyramid: Golden rules and organisational measures towards a more inclusive work environment. Journal of Nursing Management, 27(7), 1522-1529.

Murray, P. A., \& Ali, F. (2017). Agency and coping strategies for ethnic and gendered minorities at work. The International Journal of Human Resource Management, 28, 1236-1260.

Narsey, W. L. (1979) Monopoly capital, white racism and superprofits in Fiji: a case study of the CSR, Journal of Pacific Studies, 5(1), pp. 66-146.

Nkomo, S. M., and Rodriguez, J. K. (2019). Joan Acker's influence on management and organization studies: Review, analysis and directions for the future. Gender, Work and Organization, 26(12), 1730-1748 
Ogbonna, E. (2019). The uneasy alliance of organisational culture and equal opportunities for ethnic minority groups: A British example. Human Resource Management Journal, 29(3), 309-327.

Olson, M. (1993). Dictatorship, Democracy, and Development. American Political Science Review, 8 (3), 567-576.

Opara, V., Sealy, R., and Ryan, M. K. (2020). The workplace experiences of BAME professional women: Understanding experiences at the intersection. Gender Work and Organization, 1-22.

Pace, D. (1978). Structuralism in history and the social sciences. American Quarterly, 30(3), 282-297.

Parkinson, G. H. R. (1972). Hegel's Concept of Freedom. In Reason and Reality (pp. 174-195). Palgrave Macmillan UK.

Pio, E., \& Essers, C. (2013). Professional Migrant women decentering Otherness: A Transnational Perspective. British Journal of Management, 25 (2), 252-265.

Pio, E., \& Syed, J. (2020). Stelae from ancient India: Pondering anew through historical empathy for diversity. Management Learning, 51(1), 109-129.

Popp, A., \& Holt, R. (2013). Entrepreneurship and being: the case of the Shaws. Entrepreneurship \& Regional Development, 25(1-2), 52-68.

Reddock, R. (1986). Indian women and indentureship in Trinidad and Tobago, 1845-1917: Freedom denied. Caribbean Quarterly, 32, (3/4), 27-49. 
Resnick, A., \& Wolff, D. (1982). Marxist epistemology: The critique of economic determinism. Social Text, (6), 31-72.

Ronback, K. (2014). Sweet business: quantifying the value added in the British colonial sugar trade in the 18th century. Revista de Historia Econo'mica, Journal of lberian and Latin American Economic History, 32, (2), 223-245.

Roopnarine, L. (2009). Indian Social Identity in Guyana, Trinidad, and the North American Diaspora. Wadabageri, 12 (3), 87-125.

Rostow, W. W. (1990). The stages of economic growth: A non-communist manifesto. Cambridge: Cambridge University Press.

Rydzik, A., and Anitha, S. (2019). Conceptualising the agency of migrant women workers: Resilience, reworking and resistance. Work Employment and Society, 1-17. $\quad$ https://doiorg.ezproxy.aut.ac.nz/10.1177/095001701988193 $\underline{9}$

Santos, B. (2018). The End of The Cognitive Empire: The coming of age of epistemologies of the South. Durham: Duke University Press.

Schneider, F. Jr. (1926). Sugar. Foreign Affairs, January 311-320.

Schultz, M., \& Hernes, T. (2013). A temporal perspective on organizational identity. Organization Science, 24(1), 1-21.

Syed, M., Santos, C., Yoo, H., \& Juang, L. (2018). Invisibility of Racial/Ethnic Minorities in 
Developmental Science: Implications for Research and Institutional Practices. American Psychologist, 73 (6), 812-826.

Suddaby, R., Foster, W. M., \& Trank, C. Q. (2010). Rhetorical history as a source of competitive advantage. Advances in Strategic Management, 27, 147-173.

Tariq, M., and Syed, J. (2017). Intersectionality at work: South Asian Muslim women's experiences of employment and leadership in the United Kingdom. Sex Roles, 77(7-8), 510-522.

Tatenhove, J., Arts, B., \& Leroy, P. (Eds.). (2000). Political Modernisation and the Environment (Vol. 24). Springer Science \& Business Media.

Tinker, H. (1974). A New System of Slavery- The Export of Indian Labour Overseas, 1830-1920. London: Oxford University Press.

Tomlinson, J., Muzio, D., Sommerlad, H., Webley, L., and Duff, L. (2013). Structure, agency and career strategies of white women and black and minority ethnic individuals in the legal profession. Human Relations, 66(2), 245-269.

Van Laer, K., and Janssens, M. (2017). Agency of ethnic minority employees: Struggles around identity, career and social change. Organization, 24(2), 198-217.

Wallerstein, I. (1987, March). The construction of peoplehood: racism, nationalism, ethnicity. In Sociological Forum (Vol. 2, No. 2, pp. 373-388). Springer Netherlands. 
Wallerstein, I. (1990). Culture as the ideological battleground of the modern world-system. Theory, culture and society, 7(2-3), 31-55.

Wasserman, V., and Frenkel, M. (2019). The politics of (in)visibility displays: Ultra-Orthodox women manoeuvring within and between visibility regimes. Human Relations, 1-23. https://doiorg.ezproxy.aut.ac.nz/10.1177/001872671987998 $\underline{4}$

Weick, K. E. (1993). The collapse of sensemaking in organizations: The Mann Gulch disaster. Administrative Science Quarterly. 38 (4), 628-652.

Zanoni, P., \& Janssens, M. (2007). Minority employees engaging with (Diversity) Management: an analysis of control, agency, and micro emancipation. Journal of Management Studies, 44(8), 1371-1397.

Zick, A., Wagner, U., Van Dick, R., \& Petzel, T. (2001). Acculturation and prejudice in Germany: Majority and minority perspectives. Journal of Social Issues, 57(3), 541-557. 